\title{
A DIVERSE SOCIETY, A REPRESENTATIVE MILITARY? THE COMPLEXITY OF MANAGING DIVERSITY IN THE SOUTH AFRICAN ARMED FORCES
}

\author{
Prof Lindy Heinecken ${ }^{1}$ \\ Department of Sociology and Social Anthropology, \\ University of Stellenbosch
}

\begin{abstract}
After providing a brief background as to why issues of diversity management within armed forces have become important internationally, this article outlines the diversity challenges facing the South African National Defence Force (SANDF). The first part of the article describes how the racial, language/ethnic and gender profile of the SANDF has changed since 1994 and the tensions this has evoked. The second part provides a brief conceptual framework against which diversity management in the SANDF can be interpreted, whereafter the various diversity management programmes instituted over the years to cultivate a respect for diversity are outlined. It is argued that the predominant emphasis on 'workplace diversity' at the cost of 'valuing diversity' has meant that existing stereotypes and tensions within the ranks have remained, with dire consequences not only for the cohesiveness and effectiveness of the SANDF, but also for civil-military relations.
\end{abstract}

\section{Introduction}

Managing diversity has become a major theme in the contemporary world, not least within the armed forces, which have not only become more diverse in terms of race and gender, but which are frequently deployed together with or within other nations. However, the manner in which armed forces deal with diversity issues differ substantially, as they are largely influenced by the political, cultural and ethnic influences emanating from broader society (Soeters and Van der Meulen 2007). Yet,

\footnotetext{
1 The author wishes to thank the two anonymous reviewers for their useful comments and critique, which have greatly improved the content and quality of this article.
} 
despite these differences, there are a number of universal reasons why diversity management has assumed greater 'political' prominence in military affairs since the end of the Cold War.

The first stems from the emphasis placed on individual rights that have obliged armed forces to review policies and practices that discriminate against women, homosexuals and ethnic minorities. In most cases, these reforms have been driven by lobby groups or legislative impediments. With respect to South Africa, it has not been lobby groups per se, but rather the need to conform to the legal imperatives spelt out in the new Constitution of the Republic of South Africa, which forbids discrimination on the grounds of race, ethnicity, gender and sexual orientation, religion and language, among others, which have driven policy reforms (Heinecken 2007:79-80).

A second reason why armed forces are pressured to become more representative is to preserve their legitimacy among key stake-holders in broader society. In many countries, it is a democratic imperative that the armed forces are broadly representative of the populace with respect to race, ethnic composition, social class, religion and gender (Baynam 1990:9-10). The general assumption is that control of the armed forces is more or less guaranteed as long as all segments of society are represented. In South Africa, the White Paper on Defence specifically states that "to secure the legitimacy of the armed forces, the Department of Defence is committed to the goal of overcoming the legacy of racial and gender discrimination" and that it will seek to create "a Defence Force that is professional, efficient, effective and broadly representative" (DOD 1996:32). In this regard, militaries have not only assumed an important 'nationalising' role, but have also served as an instrument to uplift the poorer and less educated segments of society, in some cases becoming the "school of the nation" (Soeters and Van der Meulen 1999:212).

A third reason why armed forces have become more concerned with issues of diversity is the growing problems of recruitment and retention associated with the shift to an all-volunteer force. A number of countries, for example, Canada, Belgium, the Netherlands and the United Kingdom to name but a few, have seen a decline in white male recruitment. Shortages, particularly in the technical and combat positions in the army, air force and navy are observed across nations. This has obliged armed forces to recruit from non-traditional pools, namely ethnic minorities (and even foreign nationals) and women, to meet their manpower requirements. Dandeker and Mason (2007:142-143) call this the "self-interest or business case" for diversity, which is driven by need, not altruism. In South Africa, we see similar declines in white male recruitment and difficulties in recruiting members with the necessary skills, especially those of 'colour'. However, here the 
need to correct past racial imbalances has tended to be more important than the need to attract and retain the necessary skills.

A fourth argument in favour of greater diversity is the argument that it improves the effectiveness of armed forces, especially in the field of humanitarian missions and in terms of civil-military cooperation. There is growing evidence that a better gender/racial mix is more suited for non-combat missions, especially in their interaction with local communities. In terms of women's participation in peacekeeping missions, their contribution assumed greater importance with the passing of United Nations Resolution 1325 in 2000. This Resolution has reaffirmed the important role of women in the prevention and resolution of conflicts and in peacekeeping, and called for gender mainstreaming to be incorporated in all multinational peace operations, as not only something that is beneficial, but essential. In South Africa, this has given fresh momentum to the greater recruitment of women, with targets being set at $30 \%$ and even higher. ${ }^{2}$

A fifth and further reason why some armed forces have been obliged to deal with issues of diversity, relates to the integration of previously adverse military groups, often from different ethnic or ideological backgrounds, to build a new army after a change in the political dispensation (Soeters and Van der Meulen 1999:2134). We see this occurring for example in Germany after the end of the Cold War and in Eritrea and South Africa after years of liberation wars (Tessema 2007:101-108). This brings an added dimension to diversity management, that of political ideology and past loyalties that have a powerful influence on workplace relations. This has meant that managing diversity has become more than just accommodating diverse groups, but dealing with the underlying tensions that cultural and ideological differences bring.

In many respects, South Africa represents a microcosm of the issues armed forces have to deal with in terms of diversity management, albeit with some unique differences. Hence, the aim of this article is to provide an overview of how the South African National Defence Force (SANDF) has dealt with the issue of diversity management. The first section of the article describes how the racial, language/ethnic and gender profile of the SANDF has changed since 1994, and the tensions this has evoked. The second section provides a brief conceptual framework

\footnotetext{
${ }^{2}$ At the recent DOD Gender Conference on Soliciting male colleagues support in pursuit of gender equality, St George's Hotel, Pretoria 20-22 August 2008, it was argued that, because of attrition, it is necessary to increase the recruitment of the number of women to $40 \%$. This aspect of diversity management is the subject of another research project and will not be discussed in detail in this article (see Heinecken and Van der Waag 2007).
} 
against which diversity management in the SANDF can be interpreted, whereafter the various diversity management programmes instituted over the years to cultivate a respect for diversity are outlined. The argument is made that the overriding emphasis on creating a representative military has been at the expense of valuing diversity, which has not only harmed work relations, but which may also have dire consequences for the long-term effectiveness of the SANDF and for civil-military relations.

\section{A diverse society, a representative military}

While in most countries the management of diversity has meant accommodating minorities, in South Africa this has involved the integration of the majority black population $^{3}$ into a minority white-dominated workplace. Years of discrimination denied many blacks access to certain jobs and sectors of society, including the military. This was to change radically when the African National Congress (ANC) came into power in 1994. Since then the government has systematically set about not only repealing various racially discriminatory laws, but also implementing others that would correct the past social and economic inequalities caused by decades of colonialism and apartheid. This included an assertive affirmative action (AA) and equal opportunities (EO) programme that would change the racial, ethnic and gender profile of the South African armed forces forever, as reflected in the following section.

\section{Racial profile}

South Africa has a multiracial and multiethnic population of 47,9 million of which black Africans (hereafter Africans) constitute 79,6\% of the population, whites 9,1\%, coloureds $8,9 \%$ and Asians 2,4\%. Thus, four out of five South Africans are (black) Africans. Whereas the former South African Defence Force's (SADF) permanent force of the early nineties was mostly white, this was to change significantly with the integration of the former revolutionary and Transkei, Bophuthatswana, Venda and Ciskei (TBVC) Defence Forces from 1994, but was still some way off the targets set by the Defence Review in 1996 (see Table 1).

\footnotetext{
${ }^{3}$ Within the South African context, 'blacks' refers to all those other than whites, namely Africans, coloureds, Indians and, more recently, Chinese.
} 
Table 1: Racial profile of general population and SANDF (as percentages)

\begin{tabular}{ccccc}
\hline Race & $\begin{array}{c}\text { Population } \\
-2007\end{array}$ & $\begin{array}{c}\text { Defence } \\
\text { Review } \\
\text { targets }^{4}\end{array}$ & $\begin{array}{c}\text { SANDF } \\
\text { 1994- post- } \\
\text { integration }\end{array}$ & $\begin{array}{c}\text { SANDF } \\
2007- \\
\text { October }\end{array}$ \\
\hline Africans & 79,6 & 64,7 & 39,2 & 69,7 \\
Coloureds & 8,9 & 10,2 & 12,6 & 11,5 \\
Asians & 2,4 & 0,75 & 1,3 & 1,2 \\
Whites & 9,1 & 25,4 & 46,8 & 17,7 \\
\hline
\end{tabular}

The Defence Review set quotas of $64,5 \%$ Africans, coloureds 10,2\%, Asians $0,75 \%$, and Whites $25,4 \%$. These targets have been met, and by October 2007, the SANDF (uniformed component) consisted of Africans 69,7\%, coloureds 11,5\%, Asians $1,2 \%$ and whites $17,7 \%$. This marks a radical shift in the racial profile of the SANDF where whites are now in effect under-represented according to the set targets while Africans are over-represented. ${ }^{5}$ However, this racial profile is not reflected at all the different rank groups and professional branches in the SANDF. At the operational level, (middle management) whites still made up more than half of the officer and non-commissioned ranks. Yet, at the lower levels, only $2 \%$ of privates were whites, while almost $90 \%$ were Africans.

\section{Language/ethnic profile}

South Africa is not only a racially, but also an ethnically diverse society. As the SANDF does not keep statistics by ethnic group, one can get a sense of this by examining ethnicity with reference to language preference. ${ }^{6}$ Whites are generally Afrikaans or English speakers, ${ }^{7}$ while Africans belong to any of the following nine different ethnic groups: Zulu, Xhosa, Pedi, Sotho, Tswana, Tsonga, Swazi, Ndebele and Venda, all with their own languages.

${ }^{4}$ Figures may not add up to $100 \%$ due to rounding off. Figures provided in Department of Defence, 2006. Annual Report, Financial Year 2005-2006, Military Printing Press, Pretoria, p. 12.

5 The statistics quoted here are for Defence Act Personnel (SANDF) only and exclude civilians working in the Department of Defence (Public Servant Act Personnel).

${ }^{6}$ As many may be of mixed origin, language preference can be seen as an indicator of identifying with a specific racial/ethnic group.

7 Whites may predominantly speak either English or Afrikaans but may not necessarily classify themselves as either English (British) or as Afrikaners given their diverse heritage. 
Currently there are 11 official languages, ${ }^{8}$ of which most speak [1] IsiZulu $(23,8 \%)$, followed by [2] IsiXhosa (17,6\%), [3] Afrikaans (13,3\%), [4] Sepedi $(9,4 \%)$ [5] Setswana (8,2\%), [6] Sesotho (7,9\%), [7] Xitsonga (4,4\%), [8] SiSwati $(2,7 \%)$, [9] Tshivenda (2,3\%) and [10] IsiNdebele (1,6\%). Although English [11] is the official language of communication, only $8.2 \%$ cite this as their first language (SSA 2007). Language is also region-specific, for example in KwaZulu-Natal most Africans speak IsiZulu, in the Eastern Cape, IsiXhosa and in the Western Cape the coloured community speaks mostly Afrikaans. As reflected in the statistics provided, vast discrepancies exist between the national and the DOD language profile (Table 2). In October 2007, 8,3\% members of the DOD indicated IsiZulu as their first language, 9\% IsiXhosa, 23,6\% Afrikaans, 7,5\% Sepedi, 8,3\% Setswana, 5,7\% Sesotho, 1,6\% Xitsonga, 2,1\% SiSwati, 3\% Tshivenda, 0,5\% IsiNdebele, and 10,3\% English (DOD 2007).

Table 2: Language profile of general population and Department of Defence

\begin{tabular}{|l|l|l|l|l|l|l|l|l|l|l|l|}
\hline Language & $\mathbf{1}$ & $\mathbf{2}$ & $\mathbf{3}$ & $\mathbf{4}$ & $\mathbf{5}$ & $\mathbf{6}$ & $\mathbf{7}$ & $\mathbf{8}$ & $\mathbf{9}$ & $\mathbf{1 0}$ & $\mathbf{1 1}$ \\
\hline Population & 23,8 & 17,6 & 13,3 & 9,4 & 8,2 & 7,9 & 4,4 & 2,7 & 2,3 & 1,6 & 8,2 \\
\hline DOD & 8,3 & 9,0 & 23,6 & 7,5 & 8,3 & 5,7 & 1,6 & 2,1 & 3,0 & 0,5 & 10,3 \\
\hline
\end{tabular}

Concerning the language profile of the DOD, Zulus are significantly underrepresented while Afrikaans speakers are over-represented. This is a legacy of the past as most former SADF members were Afrikaans-speaking and so are many civilian employees and coloureds serving in the DOD. For many Africans, Afrikaans is still negatively associated with apartheid. Given that almost a quarter of those serving in the DOD cite Afrikaans as their first language, it is still widely spoken in the SANDF, particularly in the South African Army, which is the largest arm of service. While many Africans who served in the former SADF could speak Afrikaans, the same does not apply for many integrated into and joining the SANDF after $1994 .^{9}$

\footnotetext{
${ }^{8}$ Language profile as recorded at last population census 2001.

${ }^{9}$ Afrikaans was (and for some still is) considered the language of the oppressor and many Africans resisted been taught in Afrikaans and those who were in exile during the years of apartheid had little exposure to the language.
} 
As the Constitution ${ }^{10}$ prohibits discrimination on the basis of language, the Department of Defence was obliged to formulate a language policy based on what it called "thread" and "link" languages. For the purposes of command and control, English is the official thread language for defence communication, supported by the appropriate link language (dominant language of region, zone, command, formation or unit). In practice, English and Afrikaans overshadow the other languages, and equitable language treatment does not translate into equality. Language is an important source of power, and English is often the second or third language of Africans. Consequently, they are at a disadvantage, especially where linguistic shortcomings are construed as a sign of intellectual inferiority, when in fact it is merely an inability to express oneself adequately.

In addition, language usage perpetuates other stereotypes that undermine the achievement of equality (Human 1996:61). Frequently, the status and intellect of persons are judged by their accent across the colour bar - whether black or white. For example, if Africans have a European rather than an African English accent they are often regarded as "coconuts" - black on the outside, but white on the inside (thus part of them). In turn, whites tend to judge such Africans as more educated and competent. ${ }^{11}$ Few whites speak the different African languages and just as Africans who cannot speak Afrikaans feel alienated by its continued use, so do whites when Africans speak in their home language.

\section{Educational disparities}

Another divisive issue is the vast disparities in educational profile of the different racial groups. The majority of South Africans grew up in segregated communities and schools where the quantity and quality of education varied significantly. Statistics for 2007 on educational attainment of those aged 25 years and older indicate that fewer than $6 \%$ of Africans and coloured women have a postschool education. In comparison, $36 \%$ of white men have a higher qualification and $29 \%$ of white women. An estimated 18\% of African women and 13\% of African men have no formal schooling. Consequently, it is not surprising that the

${ }^{10}$ The Constitution of the RSA, Act No 108 of 1996 makes it clear that "every person shall have the right to use the language of his or her choice (Section 30); that no person shall be unfairly discriminated directly or indirectly against on the basis of, among others, language (Section 9[3]); and further that each person has the right "to receive education in the official language or languages of their choice in public educational institutions" (Section 29 [2]).

${ }^{11}$ This is something I have observed in my 17 years of service in the Department of Defence and which was confirmed in discussions with others on the topic. 
unemployment rate is highest among African women (32\%) and African men (29\%) and lowest among white males (5\%) (SSA 2007:23-25).

Comparing this with the overall educational profile of the Department of Defence (DOD), reveals stark disparities. Of those whose educational qualifications have been captured on the DOD personnel database, only $4,7 \%$ have some form of higher education (degree, diploma or technical qualification), of which $61 \%$ are whites, $12 \%$ coloureds, $2 \%$ Indian and 25\% Africans. While these statistics should be read with some caution, as $33 \%$ of DOD members' level of education has not been recorded in the personnel database, they nonetheless illustrate the discrepancies in education based on the available data. ${ }^{12}$ This has a significant impact on the management of diversity, as poor education often contributes to feelings of incompetence.

With reference to the SANDF, Menon and Kotze (2007:86) report that Africans find it "difficult to lead well-educated and trained white subordinates, and experienced a sense of disempowerment". Exacerbating this is that whites are said to consider "blacks inherently less capable, innately inferior and intellectually limited" and have doubts about their capabilities when in positions of power and authority (Human 1996:54-55). Unfortunately, these perceptions of racial incompetence are often made worse by AA, where blacks are perceived to have been promoted to high positions without the necessary experience and/or training.

\section{Managing diversity: Explaining the concepts}

All these issues have complicated diversity management in the SANDF. Before discussing this, it is necessary to clarify the use of certain terms that are frequently confused. Often the terms 'affirmative action', 'employment equity' and 'managing diversity' are used interchangeably, whereas in effect they mean different things. Affirmative action (AA) is a politically driven programme that includes laws, programmes and activities designed to redress past imbalances and ameliorate the conditions of specified groups who have been disadvantaged on the grounds of race, gender and disability (Uys 2003:32). AA is the process used to achieve the desired outcome of greater equality of opportunity and ultimately, employment equity. One of the means to ensure employment equity, according to the Employment Equity Act of 1998 (Section 2) is the systematic "elimination of unfair discrimination and the

${ }^{12}$ Of the total number of 76159 uniformed and civilian personnel serving in the Department of Defence, the educational level of 24908 (almost 33\%) was not recorded. The statistics calculated are for those whose education has been recorded. 
establishment of specific measures to accelerate the advancement of those previously disadvantaged".

Both AA and EO are aimed at creating employment opportunities and ensuring the promotion of those previously disadvantaged. AA is therefore seen as a means of correcting historical injustices and an attempt to level the playing fields where everyone can compete on an equal basis, thereby achieving employment equity (Thomas 1996:6). This is why AA has often been equated with terms such as 'corrective action', 'black advancement' or 'positive action' (Uys 2003:32). AA is not a proactive strategy, but a reactive strategy based on statutory and moral imperatives that compel organisations to include women and other groups into the mainstream. According to Thomas (1991:18-21), historically this process has evolved through different phases: the passive and the pipeline or hierarchy scenario.

The 'passive scenario' is found where organisations take the necessary steps to ensure compliance to AA policy and to eliminate blatant racism and sexism within the workplace with the assumption that this will create equal opportunity. When women and blacks fail to advance, they blame this on a lack of experience or education, but fail to implement any form of remedial action as this is regarded as constituting reverse discrimination or preferential treatment. The 'pipeline scenario' moves beyond the intervention-free approach to increase the number of previously disadvantaged groups by supporting development programmes. However, this approach is still based on the assumption that a poor educational background or lack of preparation is the major barrier to upward mobility. The 'upward hierarchical or mobility scenario' is motivated by moral considerations. Organisations adopting this approach to AA actively recruit and promote women and blacks by providing 'special' training, setting targets for the number to be developed and promoting and setting up mentoring and tracking systems. The way the SANDF has approached AA has progressively moved towards this latter approach.

Whatever the approach, the underlying assumption of all AA initiatives is that interventions are necessary to 'better equip' blacks and women for corporate life. According to Thomas (1991:23), "AAs intent was to fulfil a legal, moral, and social responsibility by initiating 'special' efforts to ensure the creation of a diverse workforce and encourage upward mobility for minorities and women". In the case of the dominant group, white males, this process is often seen as reverse discrimination and preferential treatment. As AA embodies a form of discrimination it often leads to resentment and tension, especially where the focus is on getting the numbers right, instead of valuing diversity (Thomas 1991:24).

While AA contributes to an increase in workforce diversity, the process itself does not encourage awareness and respect for diversity in the workplace. Often 
managing diversity and affirmative action is considered as one, but this is incorrect. Managing diversity as an organisational strategy that "seeks to harness and capitalise on sensitivity to gender, racial, cultural and other more salient differences to create a more dynamic and competitive organisational culture" (Uys 2003:33). This encompasses a range of activities aimed at making managers or leadership more aware of the values and assumptions of different diverse groups, which may affect the way they "cooperate, compete, communicate, plan, organize and are motivated" (Horwitz, Bowmaker-Falconer and Searll 1996:139). The ultimate aim is to develop an organisational environment in which all employees can contribute to the strategic and competitive advantage of the organisation (Thomas 1996:10). Failure to assimilate and manage diversity can, according to Horwitz et al. (1996:140) lead to "misconceptions, poor work relations, underperformance and discrimination".

Managing diversity is a multifaceted concept and embraces the recognition and value of cultural diversity. However the problem with many managing diversity initiatives is that they often reinforce underlying stereotypes by focusing on national or ethnic culture and not on the relevance of cultural differences that can improve "cultural knowledge" (Human 2005:14). According to Human (2005:14), this has given rise to a tension between those who have adopted a more generalised (or maximalist) approach to diversity training, using nationality, ethnic, religious or gender (such as Hofstede) in diversity training, and those who have adopted a more detailed (minimalist) approach, which tries to identify other cross-cutting cultural and social variables, such as education, language and social class that impact on diversity management.

Given the complexity of this subject, one can understand why "many so-called managing diversity programmes not only confuse the relationship between managing diversity and affirmative action and employment equity, but also confuse managing diversity with managing culture" (Human 1996:51). In the SANDF, the focus has been primarily on workplace diversity to meet equity targets, although there have been some remarkable attempts to introduce programmes that attempt to create awareness and respect for cultural diversity.

\section{Workforce diversity versus managing diversity}

According to Menon and Kotze (2007), the SANDF has adopted a 'hard' approach to diversity management, which has tended to equate managing workplace diversity with affirmative action. This has meant that other cross-cutting social variables, such as education, language, cultural and political differences that underlie existing tensions across race and gender, have often not been adequately addressed. 
In the following section, I attempt to explain how the emphasis on workplace diversity or 'representivity' has influenced work relations in the SANDF.

\section{Affirmative action, integration and political expedience}

Since the formation of the SANDF in April 1994, the transformation process has been dominated by the need to reform the racial and gender profile of the armed forces (Heinecken 2005:74-96). This approach was supported by statutory intervention in terms of AA and EO legislation, which has effectively changed the racial profile of the SANDF, with the added political twist that many of the new military leaders are from the former revolutionary forces. To illustrate this, by April 1997 after integration ${ }^{13}$ was complete, the senior-command leadership positions Brigadier-General to General within the SANDF comprised of MK (14\%) officers, APLA (1\%), TBVC (4\%) and SADF (81\%). By October 2007, whilst comprising only $19 \%$ of the total force strength of the SANDF, former MK and APLA represented $46 \%$ of officers in senior-command leadership, whilst former SADF members represented $47 \%$ and the homeland armies $7 \%{ }^{14}$

Table 3: Composition by former force and rank (1997 and 2007) (as percentages)

\begin{tabular}{ccccc}
\hline & $\begin{array}{c}\text { Former force } \\
1997\end{array}$ & $\begin{array}{c}\text { Rank profile } \\
\text { Brig-Gen -Gen }\end{array}$ & $\begin{array}{c}\text { Former force } \\
2007\end{array}$ & $\begin{array}{c}\text { Rank profile } \\
\text { Brig-Gen - Gen }\end{array}$ \\
\hline MK & 15 & 14 & 13 & 37 \\
APLA & 5 & 1 & 6 & 9 \\
TBVC & 11 & 4 & 7 & 7 \\
SADF & 58 & 81 & 32 & 47 \\
SANDF* & 11 & 0 & 42 & 0 \\
\hline
\end{tabular}

Note: *The SANDF composition reflects those who joined the SANDF after 1994 and who had no former force affiliation.

\footnotetext{
${ }^{13}$ Integration refers to the amalgamation of the four former homeland armies, namely the Transkei Defence Force (TDF), Bophuthatswana Defence Force (BFD), Venda Defence Force (VDM) and Ciskei Defence Force (CDF) (collectively known as the TBVC forces) and the former non-statutory revolutionary forces of Umkhonto we Sizwe (MK), the liberation army of the ANC and the Azanian People's Liberation Army (APLA) of the black consciousness Pan African Congress (PAC), which collectively formed the new South African National Defence Force in April 1994. Included later was the KwaZulu Self-Protection Force (KZSPF) of the Inkhata Freedom Party (IFP).

${ }^{14}$ Figures for KZSPF not provided in latest statistics.
} 
This transfer of racial/political power has acute implications for race relations within the SANDF. Former SADF officers tend to be conformist, authoritarian and bureaucratic. In contrast, former revolutionary officers operated in a culture free from rigid regulations and prescribed channels, they valued initiative and were highly politicised. This has led to a clash in leadership styles where former MK and APLA officers still tend to rely on their former networks for information, advice and support rather than channelling issues through the chain of command. Former loyalties continue to persist to the extent that "cadres often refuse to testify against each other" (Setai Report 2001). This not only impacts negatively on discipline and morale, but also disrupts the chain of command. Consequently, Van Ryneveld (2006:13) claims that "the centuries-old military principle of unified command has been lost". This is exacerbated by the fact that white officers are often reluctant to take disciplinary action for fear of reprisal, of being accused of being racist or due to the repercussions this may have for their own careers (Heinecken, Nel and Janse van Vuuren 2003:93).

As reflected in Table 3, former non-statutory forces have benefited greatly from AA and, according to Honey (2003:29), many loyal guerrilla fighters have been rewarded with high ranks, often without due consideration of experience, skills or age. Many have little experience of managing a bureaucracy or planning large-scale military operations and this has given rise to considerable tension among whites, who perceive that military competency has been sacrificed for the sake of political expediency. South African Air Force (SAAF) instructors and former fighter pilots, for example, say that the relaxation of standards where pupils who only manage a $40 \%$ pass rate still qualify as fighter pilots is "nothing short of a death sentence" (Makings 2004:38).

The Air Force and Navy face serious challenges as pilots, sea-going officers, engineers and highly skilled technicians leave and cannot be replaced with persons of colour. This has been aggravated by AA policies that have driven too many whites out of the SANDF before they could transfer their knowledge and skills, and those with the necessary skills are often denied opportunities due to the fact that they are white, despite the skills shortage ${ }^{15}$ (Heinecken 2007:83-84). Therefore, it is not surprising that an EO and AA climate survey during 2005 indicated that whites $(64 \%)$ are the least positive about the SANDF's AA policies, with coloureds becoming increasingly more negative (DOD 2006). Coloureds claim that in the past

\footnotetext{
${ }^{15}$ This has often resulted in posts staying vacant for long periods in the hope that the 'right" appointment of colour can be made. This not only impacts on the morale of others having to carry the work load until such appointments can be made, but on the organizational effectiveness of the SANDF as well.
} 
they where not 'white enough' and now they are discriminated against for not being 'black enough'. Yet, despite the fact that Africans have benefited greatly from AA, $41 \%$ still felt that "equal opportunities" are not available to them, while $49 \%$ of whites thought everyone has equal benefits.

Although racial tolerance may have improved, one cannot say that there is racial harmony in the SANDF. As one witness in the Setai Commission stated, "if you have black and white, you will have racism, and if you have black and black of different cultures, you'll still have problems" (Setai Report 2001). There is still a high degree of racial tension and racism in the SANDF. However, much of the racial tension is driven by the past inequalities (and feeling of inferiority) in education and perceived standards of training, rather than race per se (Dube and Gifford 1999:1-2).

\section{Gender, sexuality and culture}

Race has dominated the discourse in the SANDF, although not to the total exclusion of gender issues. Since 1996, great strides have been made to improve the gender profile and to remove barriers that restrict the full integration of women. To illustrate this, the percentage of women serving in the SANDF increased from an average of $11 \%$ in 1994 to $13 \%$ in 2000 to $19,5 \%$ in October 2007. In addition, women comprise almost $11 \%$ of the senior leadership positions rank Brig-Gen and above. The question is whether this is enough. Some claim that women must number at least $15 \%$ of an organisation to be viewed as more than a token, and $30 \%$ if they are to be a critical mass to ensure that they are heard (Pinch 2006:6). Here it is of interest to note that, while only $11 \%$ of women served in the senior ranks of BrigGen and above by October 2007, they were well represented in the junior officer ranks of $2^{\text {nd }}$ Lieutenant/Lieutenant $(35 \%)$ and Captain (36\%). Should these women remain in the military, a critical mass of $30 \%$ proposed by government may well be achieved within the next decade.

The racial/gender profile of the SANDF has also changed markedly over the past decade (Table 4). In 1994, white women made up $81 \%$ of the female component; today they represent $22 \%$ with the majority being African women $65 \%$. While they are well represented in the lower officer ranks (around 22\%), at troop level white women make up less than $3 \%$ of privates. This may pose some challenges for the SANDF in future, especially where women's leadership is not be accepted by male counterparts. 
Table 4: Racial gender profile of the SANDF (as percentages)

\begin{tabular}{cccc}
\hline & 1994 & 2000 & 2007 \\
\hline Asians & 0,8 & 1 & 1 \\
African & 13 & 48 & 65 \\
Coloured & 5,2 & 8 & 12 \\
White & 81 & 43 & 22 \\
\hline
\end{tabular}

Note: Figures cited for only uniformed women serving in the SANDF (civilians excluded).

As for career options, whereas in the former SADF women served only in supportive roles such as finance, personnel, logistics, intelligence, medical services and welfare, today women in the SANDF have an open career. While many still serve in these supportive roles, by October 2007, an estimated $14 \%$ served in the armour corps, $18 \%$ in artillery, $8 \%$ as infantry, $21 \%$ in combat navy and $6 \%$ as aircrew (including pilots). ${ }^{16}$ Women receive the same training as men and there is no gender discrimination except with respect to facilities and certain drill adaptations that are considered fair discrimination based on physiological differences. This does not mean that prejudice against women serving in the more hard-core combat roles does not exist (Heinecken 2002:715-728).

A survey among women in 2001 showed that $60 \%$ of women believed that men are threatened by female counterparts performing similar duties. In a follow-up study in 2004, focusing specifically on the deployment of women in peace support operations, this view persisted (DOD 2004:5). Men were particularly guarded in their views of whether women should serve in the Special Forces that require exceptional endurance, courage, mental strength and the ability to operate alone and far behind enemy lines for lengthy periods of time. Men still consider women more suited to support positions because they are physically weaker. In reality, few women have managed to complete the elite paratrooper or Special Forces courses successfully, but even where they have 'out-maled men', they frequently continue to feel inferior.

Besides gender differences, the way women perceive their integration into the military as differing by race. Menon and Kotze (2007:86) found that white women feel less empowered and integrated in the military because they are not regarded as professional "career" soldiers, serve mainly in support roles, and face role ambiguity

\footnotetext{
${ }^{16}$ Although this may sound impressive, many of these women may wear the corps badge but are employed in personnel or logistical posts.
} 
in terms of home-maker versus career roles. Black women experience disempowerment due to cultural impediments, sexual harassment, family stress and their greater childcare responsibilities. This shows that there is a cultural-gender divide, where white women feel disempowered due to institutional constraints, while black women experience subordination rather in terms of traditional African culture.

An aspect that is often ignored, but which is central to the discrimination women experience in the military is the double standard of sexual morality that both reflects and reinforces gender inequality. Within the military, women are often judged by their sexuality in a variety of ways. Mankayi (2006:44-64) for example, found that men accuse women of using their sexuality to "achieve success in the system", in other words to get promotion or preferential treatment. Women's sexual conduct is also judged differently. Unlike in the case of men, where sexual prowess is admired by peers, sexual assertiveness in women is seen to subvert military discipline and authority. For a woman to be a respected soldier she needs to be an honourable woman or face being assigned derogatory labels such as 'state mattress', 'whore' or 'slut', or otherwise 'lesbian' (Mankayi 2006:59). Sexual harassment and abuse continues to be a major problem facing women serving in the SANDF, although this is significantly underreported for a number or reasons, such as the impact it may have on their future career prospects (Maughan 2006:1).

The rights of homosexuals in the SANDF have not yet featured prominently on the diversity agenda of the SANDF. Although homosexuality is legally permitted it is a "silent right" and has remained in the private sphere, but this does not mean that discrimination does not exist (Heinecken 1999). An Equal Opportunity survey conducted in 2003 showed that there is substantial prejudice and stereotypes regarding gays and lesbians. These range from concerns about the impact homosexuals may have on the spread of HIV/Aids, possible abuse of authority (seniors harassing juniors), the impact "openly gay" may have on morale, the impact on combat effectiveness, the sharing of the same facilities and issues of immorality. Most felt that homosexuals 'are still in the closet' because they are afraid of being rejected, scorned, oppressed, victimised, criticised and publicly judged (EOCD 2004). As such, few incidences have been reported.

\section{Ethnicity and cultural accommodation}

Besides race and gender, there is the issue of ethnic and cultural diversity. Many of the present military traditions have British origins, and for years the SADF was dominated by Afrikaner Christian culture, which, according to Mashike (2007:614), was equated with military culture. As such, many former SADF members "found it 
difficult to accept members wearing traditional decorations such as sangoma ${ }^{17}$ bracelets" and there was little understanding of and sensitivity for different cultural practices. Many Africans still feel that their culture is not accommodated within the "SANDF culture". Typical problems experienced include the lack of recognition by superiors of the importance assigned to certain cultural ceremonies, the need to attend funerals of extended family members, the desire to consult traditional healers and to communicate with the ancestors and the acceptance of customary marriages and dependants (Setai Report 2001:34).

To accommodate this, an array of policies have been either adapted or implemented to include the various cultural practices and beliefs of members. The SANDF Dress Policy was revised to allow members to wear certain religious adornments, for example, the Zulu custom of Isiphandla (a piece of cattle or goat skin worn on the wrist), Lakshimi string (band of seven strands of red cotton), the cultivation of a beard and a moustache by men (to show Islamic, Jewish or Shembe orthodoxy), the fez or turban worn by men (prescribed by various Islamic traditions) and the official mourning button or band (DOD 2002). In addition, a special leave dispensation was introduced that allows members up to five days "special responsibility" leave to attend funerals (DOD 2003).

The African practice of having multiple spouses (up to five wives) has been accommodated as has customary marriages. Life partners are also recognised, whether this is of two persons of the opposite or the same gender. This entitles the dependants to enjoy the same benefits as dependants of Western marriages, including medical benefits. At present, the right to consult traditional healers instead of registered medical practitioners is not recognised and members have to take normal leave instead of sick leave if they wish to do so. This remains a point of contention, but increasingly, as time goes by, policies and practices are being adapted to accommodate African traditions and cultural practices. Then again, many young Africans who have come to adopt a Westernised value system, find themselves in conflict with their own traditional culture as they are pressurised to conform to traditional rituals such as circumcision, respect for elders, the role of traditional healers, and so forth.

Another cultural aspect is the tension between individualism and collectivism. In general, whites display a stronger sense of individualism, where merit and individual performance serve as strong incentives to achieve. Africans tend to be more collectivist, stressing sharing "ubuntu" (humaneness) and a sense of community

\footnotetext{
${ }^{17}$ Sangomas are traditional healers and are believed to possess special healing powers.
} 
(Eaton and Louw 2000). Individual self-interest is frowned upon, especially if it is to the detriment of the group. This has led to some tension on military courses, where whites prefer to be evaluated individually, rather than as part of a syndicate or group. This too is changing. A study by Van Dyk and De Kock (2004:90-95) among young officers attending the South African Military Academy found that there was no longer the extreme adherence to forms of individualism or collectivism assigned by race. Thus, one also needs to consider the "generation gap" in managing diversity, a dimension frequently ignored in diversity programmes.

\section{Managing cultural diversity}

Based on the preceding discussion it is clear that managing diversity within such a diverse environment is extremely complex and it has not been met with great success in South Africa (Grobler, Marnick, Carrell, Elbert and Hatfield 2006:79). The same applies to the SANDF, which has introduced various programmes to increase employee knowledge on multi-cultural issues and to promote racial tolerance. In most cases, the approach has been typically "maximalist", dealing with culture in terms of ideal-type national differences (Hofstede 1991). According to Human (1996:51), this approach is often "value-laden and can "create either positive or negative self-fulfilling prophecies". This could be one of the reasons for the failure of the first diversity management programme implemented in the SANDF. ${ }^{18}$

Shortly after integration in 1994 and before AA started in earnest, the SANDF first tried to approach diversity management by implementing a truth and reconciliation process referred to as the Psychological Integration Programme (PIP). The first phase was for members to discuss their feelings of guilt, bitterness, fear or anger - to get these feelings 'out in the open' - so that all could be sensitised to the different perceptions that exist. People were obliged to reveal their private feelings and subjected to uncomfortable and invasive psychological exercises. After this, the next step was to address aspects of cultural diversity in order to create an awareness of the different cultures. The last phase aimed to bring about unity among the many diverse groups that needed to be integrated (Heinecken 2007:88-89).

PIP failed dismally in its attempt to create respect for cultural diversity on account of a number of reasons. The inability of facilitators to defuse tensions that arose in the first phase, created even deeper sentiments of resentment. The facilitators focused on the ills of apartheid, which made former SADF personnel feel that they have been unfairly accused and blamed for actions for which they were not

18 For a more detailed overview of all the different diversity programmes implemented, see Heinecken (2007:77-94). 
directly responsible. The result was that, instead of creating unity, the programme increased divisiveness and animosity and exacerbated existing tensions. According to Von Bergen, Soper and Foster (2002:24), this is a common mistake in diversity management, "namely, that respect for diversity will be enhanced if the sexism and racism of individual employees is confronted, challenged and eliminated". Consequently, the facilitators failed to make the transition to the last phase, to facilitate unity. As a result, the programme lost credibility and was abandoned.

The next attempt was to include diversity management as part of the Civic Education Programme of the Department of Defence. The hard lessons learnt from PIP led the SANDF to move away from the issues of race, but towards an explanation of what constitutes culture, how to bring about cultural change and the negative consequences of stereotypes and prejudice. Civic education formed part of all military developmental courses. The idea was that everyone in the DOD would gain an understanding of what management of diversity and equal opportunities entails. However, as with PIP the lack of adequately trained personnel to present the cultural diversity programmes resulted in it being disbanded towards the end of 2003. This component of the Civic Education Programme was replaced by a section focusing on shared values (DOD 2003). The shift was an attempt to move away from the focus on cultural differences to the need to create one universal military culture acceptable to everyone serving in the SANDF, irrespective of race, military background, creed, religion or gender. This was the first real attempt to create a more universal organisational culture based on core values within which diversity can be tolerated, valued and accommodated.

After the creation of the Equal Opportunities Chief Directorate (EOCD), this directorate developed its own diversity management course based on the Equal Opportunities Advisors Course presented at the Defence Equal Opportunity Management Institute (DEOMI) in Florida in the mid-nineties onwards. In the US armed forces, DEOMI has a long and successful history of dealing with issues of racial discrimination, gender issues and sexual harassment (Moskos 2007:16). It also trains equal opportunity advisers and the SANDF has sent numerous members to attend these courses. Subsequently, the EOCD developed its own courses to 'train' people how to manage diversity and deal with labour relations matters. The EOCD five-week course was designed to alert designated officers ${ }^{19}$ on the nature, origin and ramifications of discrimination and to increase their knowledge and

\footnotetext{
${ }^{19}$ Previously, this was the task of the multi-tasked functionaries, who served at the various general support bases. However, with the restructuring of the SANDF, units now nominate a specific person in the unit to deal with these issues, such as the Adjutant or Communications Officer.
} 
understanding of EO and AA. The topics discussed during these courses included aspects relating to socialisation, communication across cultures, power and discrimination, racism, sexism and religious discrimination, sexual harassment, conflict management and affirmative action.

Besides this training course, middle management was also encouraged to attend a four-day management of diversity seminar, one for middle-ranking officers (Captains and Majors) and another for Warrant Officers and Senior NonCommissioned Officers. This course was divided into various phases. In the first phase, participants were requested to expand on how they perceive the concepts of race, gender, ethnicity, culture, attitudes, personal differences and socio-economic class. Here the facilitators explained that there are different layers of diversity based on (1) one's own personality traits, (2) internal dimensions of diversity as a result of socialisation, (3) external influences such as income, personal habits, religion, educational background, and lastly (4) organisational factors, which include aspects such as seniority, division, work location, union affiliation and management status. Hereafter, the way these four layers of diversity filter one's own perception of the world and of others were examined. Participants were requested to explain how these perceptions and stereotypes impact on communication and relationships in the work environment. They were also asked to debate how this could influence mission readiness and goal accomplishment (Heinecken 2007:90-91).

Having seen how diversity filters can influence work relations, the impact of communication in a culturally diverse work setting was then examined within this seminar. Specific attention was paid to factors that shape prejudice based on race and gender, the different sources of power various groups have (such as education, language, military background) and how certain stereotypes and perceptions influence one's behaviour. The final phase of the seminar looked at the benefits of having a diverse workforce and the long-term advantages of managing diversity effectively. By means of practical examples it was illustrated how this improves the utilisation of the organisation's human capital, how it can reduce interpersonal conflict, enhance mutual respect, foster a shared organisational vision and commitment, stimulate innovation (as more ideas from different viewpoints lead to better solutions to everyday problems) and how it can improve productivity and organisational effectiveness.

Unlike the emphasis on AA and EO, which have merely brought about workplace diversity, the latter programmes tended to adopt a more minimalist approach to diversity management with the focus on cultural diversity. Unfortunately, these programmes where never fully institutionalised and they are no longer presented, some claim because there is not the capacity to do so, others that 
they are no longer necessary. After all, the political imperative of workplace diversity has been achieved.

\section{Conclusions}

Largely as a result of government's assertive AA policies, the South African armed forces are for the first time in history broadly representative of society. The targets set by the Defence Review in 1996 have been exceeded. National commitment to promote not only racial, but also gender equality has added a new dimension to diversity management in the SANDF. Whereas initially the focus was on correcting past racial imbalances, in recent years the shift has been on improving the gender representation not only in terms of numbers, but also across all branches (including combat branches). However, getting the numbers rights means nothing, if those representing the numbers are not valued and respected. Although many women now serve in traditionally male-dominated branches, they have not reached a sufficient critical mass to be fully accepted as equals, nor has the unique contribution they can make been fully endorsed.

This may change in future as the SANDF's gender mainstreaming initiatives take hold. At a recent conference on soliciting male support for gender equality, an appeal was made for men to support gender mainstreaming, to join the fight against gender inequality and to recognise the unique contributions women can make. While their value is slowly being acknowledged, the challenges greater numbers of women serving in the armed forces pose in terms of return on investment, retention, their unique needs as women, issues of cultural subordination and sexual abuse have not been fully grasped. The extent to which these factors and the greater deployment of women on peacekeeping operations may have on operational effectiveness, remains to be seen. In terms of diversity management, this has not received enough attention primarily because the focus has been on getting the numbers right.

While the SANDF has made great steps in removing racial and gender discrimination and improving its legitimacy among the broader populace, this has come at a price. The exodus of a large number of experienced white SANDF officers, before their skills could be adequately transferred has evoked concern. Yet, at the same time, AA continues to alienate and frustrate many whites who remain clustered in the middle ranks. Despite their loyalty and long-term experience, they recognise that political expedience counts more when it comes to appointments and promotions. The following comment by a senior white naval officer highlights their frustration: 
I feel that as a White senior officer with scarcely needed skills in a branch that is not attractive to Africans my service is no longer wanted or needed based on the colour of my skin. I find this very hard to accept as I serve my country and service [arm of service] just as loyally as in the past. My goal of attaining rank after a successful career is no longer achievable. For the first time I need to think of another career in the medium term (Heinecken 2007:83).

This sense of alienation has left many disillusioned, demoralised and resentful. Drawing on lessons from the private sector, Human (2005:52) has pointed out that "organisations that play the numbers game tend to lose staff that are not from the dominant group". This has been the case in the SANDF, which has not only affected retention, but also recruitment of minority groups. Many white youth aspiring to a military career have opted to join the armed forces of other commonwealth countries, even sacrificing their citizenship to do so. Other long-serving experienced white officers and non-commissioned officers have in turn opted to join the growing private security sector, which has evoked great political concern.

Although the DOD's AA and EO strategies have brought about the desired workplace diversity, one cannot say that these policies have embraced the unique strengths diversity has brought. The hard approach to diversity management has not led to a productive environment where all feel valued and where everyone's talents are fully recognised. Despite various attempts to improve the understanding of how culture and power impact on workplace relations, such attempts have been met with limited effect as they have not formed part of the overall human resource strategy of the SANDF. Whether this is due to a lack of capacity, or because these programmes are no longer considered necessary since the military is sufficiently representative, is an open question. The fact that minority groups (whites, coloureds and Indians) feel increasingly alienated does not appear to be an issue of great political concern, possibly because former revolutionary soldiers have benefited greatly from the DOD's AA and EO policies.

As many party loyalists come to dominate the senior and middle officer ranks, concern is raised about the impact this may have on the political neutrality of the armed forces. The opposition party, the Democratic Alliance, has warned that the "ANC is slowly but surely taking control over the defence force" (Van Eeden 2005:5). In the SANDF, former force and past political loyalties have been more of a dividing force than ethnicity. On this point it would be interesting to observe to what extent appointments of senior leadership may change should Jacob Zuma assume presidency, given the under-representation of Zulus in the SANDF. How 
these racial and ethnic tensions will affect civil-military relations in this fledgling democracy is yet to be seen, but it should be closely monitored.

For some, diversity management may be a 'soft' issue in terms of defence priorities, but it could have 'hard' consequences for the SANDF. Not only does a lack of sensitivity to diversity issues increase misconceptions, leading to underperformance, discrimination, ill-discipline and poor work relations, but it also affects the operational effectiveness and legitimacy of the armed forces. Should the SANDF become unrepresentative and should leadership continue to comprise of party loyalists, then there is some unease over the long-term impact this may have for civil-military relations and the political stability of South Africa. Recent events in Zimbabwe and our own apartheid legacy should be sufficient warning for us to take diversity management more seriously.

\section{REFERENCES}

Anon. 2005. RSA Armed Forces Face 'Danger' as Regional Security Roles Expand, Budget Declines. The Star, 31 August:15.

Baynam, S. 1990. Defence and Security Issues in a Transitional South Africa. International Affairs Bulletin, 14(3):1-14.

Dandeker, C and Mason, D. 2007. Ethnic Diversity in the British Armed Forces, in J Soeters and J van der Meulen (eds.). Cultural Diversity in the Armed Forces: An International Comparison. London and New York: Routledge, Taylor and Francis Group.

Department of Defence (DOD). 1996. South African White Paper on Defence. Pretoria: Department of Defence.

Department of Defence (DOD). 1998. White Paper on Defence and Defence Review. Pretoria: Department of Defence.

Department of Defence (DOD). 2001. Survey of Women Integrated into Combat Roles. Pretoria: Department of Defence.

Department of Defence (DOD). 2002. SANDF Dress Policy Instruction Amendment No 5: Wearing of Religious and Medical Adornments by SANDF Members in Uniform. HR SUP CEN/CER/R/406/11/B, 25 March.

Department of Defence (DOD). 2003. Department of Defence Policy on Shared Values. Department of Defence Instruction Policy and Plan No 00075/2002, (Policy and Planning Division). 
Department of Defence (DOD). 2004. Focus Group results regarding Women in Deployment Conducted in the DOD. DS/EOCD/R/106/30/5, January-October 2004.

Department of Defence (DOD). 2006. Equal Opportunities and Affirmative Action Climate Survey. 077/IG DOD EA/05-06. Pretoria: Centre for Effect Analysis, Defence Inspectorate.

Department of Defence (DOD). 2007. Personnel Statistics. Pretoria: Department of Defence.

Dube P. and Gifford G. 1999. Killing Spree Triggers Rethink on Integration. The Sunday Independent, 19 September:1-2.

Eaton, L and Louw, L. 2000. Culture and Self in South Africa: IndividualismCollectivism Predictions. The Journal of Social Psychology, 140(2):210-217.

Equal Opportunities Chief Directorate (EOCD). 2004. Focus Group Results Regarding Homosexuality in the DOD conducted in the Western Cape from 27 January-6 February 2004, DS/EOCD/R/106/30/5, 24 March.

Grobler, P, Marnick, S, Carrell, M, Elbert, N, \& Hatfield, R. 2006. Human Resource Management in South Africa ( $\left.3^{\text {rd }} \mathrm{ed}\right)$. London: Gengage Learning EMEA.

Haralambos, M, Holborn, M and Heald, R. 2008. Sociology: Themes and Perspectives $\left(7^{\text {th }}\right.$ ed), London: HaperCollins Publishers.

Heinecken, L. 1999. The Silent Right: Homosexuality and the Military. African Security Review, 8(5):43-55.

Heinecken, L. 2002. Affirming Gender Equality: The Challenges facing the South African Armed Forces. Current Sociology, 50(5):715-728.

Heinecken, L. 2005. South Africa's Armed Forces in Transition: Adapting to the New Strategic and Political Environment. Society in Transition, 36(1):74-96.

Heinecken, L. 2007. Diversity in the South African Armed Forces, in J Soeters J and J van der Meulen J (eds.). Cultural Diversity in Armed Forces: An international Comparison. London and New York: Routledge Taylor and Francis Group.

Heinecken, L, Nel, M, and Janse van Vuuren, J. 2003. Military Discipline: Where are We Going Wrong? Strategic Review for Southern Africa, 2003, XXV(1):88-106.

Heinecken, L and Van der Waag, N. 2007. Gender Integration in Peace Support Operations: Old and New Challenges facing the South African Armed Forces. Paper presented at the Conference on Deployment Challenges of Peacekeeping Operations in Africa, South African Military Academy, Saldanha, 10-12 September 2007. 
Hofstede, G. 1991. Cultures and Organizations: Software of the Mind, Berkshire: MacGraw-Hill

Honey, P. 2003. The Battle for Survival. Financial Mail, 24 October:29.

Horwitz, F, Bowmaker-Falconer, A, and Searll, P. 1996. Human Resource Development and Managing Diversity in South Africa. International Journal of Manpower, 17(4/5):134-151.

Human, L. 1996. Managing Workforce Diversity: A Critique and Example from South Africa. International Journal of Manpower, 17(4/5):46-64.

Human, L. 2005 Diversity Management of Business Success, Pretoria: JL van Schaik.

Makings, R. 2004. Lower Standards a Death Sentence. Sunday Times, 30 October:38.

Mankayi, N. 2006. Male Constructs and Resistance to Women in the Military, Scientia Militaria: South African Journal of Military Studies, 34(2):44-64.

Mashike, L. 2007. Blacks can Win Everything, but the Army: The Transformation of the South African Military between 1994-2004. Journal of Southern African Studies, 33(3):601-618.

Maughan, K. 2006. SANDF Peacekeepers Face Litany of Sex Charges. Pretoria News, 4 November:1.

Menon, S and Kotze, E. 2007. Human Resource Integration in the South African Military: A View from the Trenches. Human Resource Management, 46(1):71-94.

Moskos, C. 2007. Diversity in the Armed Forces of the United States, in J Soeters and J van der Meulen (eds.). Cultural Diversity in the Armed Forces: An International Comparison. London and New York: Routledge, Taylor and Francis Group.

Pinch, FC. 2006. An Introduction to Challenge and Change in the Military: Gender and Diversity Issues, in Franklin C Pinch, Allister T. MacIntyre, Phyllis Browne \& Alan C. Akros (eds.). Challenge and Change in the Military: Gender and Diversity issues. Ottowa: Canadian Forces Leadership Institute, Canadian Defence Academy.

Republic of South Africa. 2006. Constitution of the Republic of South Africa. Pretoria: Government Printer. 
Setai Commission Final Report (Setai Report). 2001. Progress Report on Integration Since June 2001, Joint Standing Committee on Defence, 12 October [Electronic]. Available: http://www.pmg.org.za [April 2003].

Statistics South Africa (SSA). 2007. Men and Women in South Africa: Five years on [Electronic]. Available: http://www.statssa.gov.za [18 October 2008].

Soeters, J and Van der Meulen, J. 1999. Managing Diversity in the Armed Forces: Comparative Conclusions, in J Soeters, and J van der Meulen (eds.). Managing Diversity in the Armed Forces: Experiences from nine countries. London: Breda: Tilburg University Press.

Soeters, J and Van der Meulen, J. 2007. Introduction, in J Soeters, and J van der Meulen (eds.), Cultural Diversity in Armed Forces: An International Comparison. London: Routledge, Taylor and Francis Group.

Tessema, MT. 2007. Diversity in the Eritrean Armed Forces, in J Soeters and J van der Meulen (eds.). Cultural Diversity in the Armed Forces: An International Comparison. London and New York: Routledge, Taylor and Francis Group.

Thomas, A, 1996. Beyond Affirmative Action: Managing Diversity for Competitive Advantage in South Africa, Randburg: Knowledge Resources.

Thomas, R. 1991. Beyond Race and Gender: Unleashing the Power of Your Total Work Force by Managing Diversity, New York: AMACOM

Uys, I. 2003. Diversity Management: Reasons and Challenges, Politeia, 22(3):3048.

Van Dyk, GAJ and De Kock, PS. 2004. The Relevance of the IndividualismCollectivism Factor for the Management of Diversity in the South African National Defence Force, South African Journal of Industrial Psychology, 30(2):90-95.

Van Eeden, J. 2005. ANC neem stadig maar seker beheer oor weermag oor (ANC slowly but surely taking over the military). Rapport, 20 February:5.

Van Ryneveld, P. 2006. SANDF has become Grim Joke. Pretoria News, 8 November:13.

Von Bergen, DW, Soper, B and Foster, T. 2002. The Unintended Negative Effects of Diversity Management, Public Personnel Management, 31(20):239-251. 